\title{
Black Fungi and Hydrocarbons: An Environmental Survey for Alkylbenzene Assimilation
}

\author{
Noemi Carla Baron ${ }^{1}$, Fernando Carlos Pagnocca ${ }^{1}$, Ayumi Aquino Otsuka ${ }^{1}$, Francesc Xavier Prenafeta-Boldú ${ }^{2}(\mathbb{D}$, \\ Vânia Aparecida Vicente ${ }^{3}$ (ID and Derlene Attili de Angelis ${ }^{1,4, *}$ \\ 1 Center for the Study of Social Insects, São Paulo State University (UNESP), Rio Claro 13506-900, SP, Brazil; \\ noemicarlabaron@hotmail.com (N.C.B.); fernando.pagnocca@unesp.br (F.C.P.); \\ ayumi.aquino@gmail.com (A.A.O.) \\ 2 GIRO Program, Institute of Agrifood Research and Technology (IRTA), Torre Marimon, Caldes de Montbui, \\ E08140 Barcelona, Spain; francesc.prenafeta@irta.cat \\ 3 Basic Pathology Department, Federal University of Paraná (UFPR), Curitiba 81531-980, PR, Brazil; \\ vaniava63@gmail.com \\ 4 Division of Microbial Resources, CPQBA, University of Campinas (Unicamp), Campinas 13148-218, SP, Brazil \\ * Correspondence: derlene@cpqba.unicamp.br; Tel.: +55-19-2139-2894; Fax: +55-19-2139-2852
}

\section{check for}

updates

Citation: Baron, N.C.; Pagnocca, F.C.; Otsuka, A.A.; Prenafeta-Boldú, F.X.; Vicente, V.A.; Attili de Angelis, D. Black Fungi and Hydrocarbons: An Environmental Survey for Alkylbenzene Assimilation. Microorganisms 2021, 9, 1008. https://doi.org/10.3390/ microorganisms 9051008

Academic Editor: Persiani Anna Maria

Received: 19 April 2021

Accepted: 3 May 2021

Published: 7 May 2021

Publisher's Note: MDPI stays neutral with regard to jurisdictional claims in published maps and institutional affiliations.

Copyright: (c) 2021 by the authors. Licensee MDPI, Basel, Switzerland. This article is an open access article distributed under the terms and conditions of the Creative Commons Attribution (CC BY) license (https:/ / creativecommons.org/licenses/by/ $4.0 /)$.

\begin{abstract}
Environmental pollution with alkylbenzene hydrocarbons such as toluene is a recurring phenomenon. Their toxicity and harmful effect on people and the environment drive the search for sustainable removal techniques such as bioremediation, which is based on the microbial metabolism of xenobiotic compounds. Melanized fungi present extremophilic characteristics, which allow their survival in inhospitable habitats such as those contaminated with hydrocarbons. Screening methodologies for testing the microbial assimilation of volatile organic compounds (VOC) are scarce despite their importance for the bioremediation of hydrocarbon associated areas. In this study, 200 strains of melanized fungi were isolated from four different hydrocarbon-related environments by using selective methods, and their biodiversity was assessed by molecular and ecological analyses. Seventeen genera and 27 species from three main orders, namely Chaetothyriales, Cladosporiales, and Pleosporales, were identified. The ecological analysis showed a particular species distribution according to their original substrate. The isolated strains were also screened for their toluene assimilation potential using a simple and inexpensive methodology based on miniaturized incubations under controlled atmospheres. The biomass produced by the 200 strains with toluene as the sole carbon source was compared against positive and negative controls, with glucose and with only mineral medium, respectively. Nineteen strains were selected as the most promising for further investigation on the biodegradation of alkylbenzenes.
\end{abstract}

Keywords: toluene; biodegradation; melanized fungi

\section{Introduction}

Alkylbenzenes are a subset of aromatic hydrocarbons in which one or more hydrogen atoms from benzene have been replaced by alkyl groups of different sizes. The simplest member is toluene $\left(\mathrm{C}_{6} \mathrm{H}_{5} \mathrm{CH}_{3}\right)$, in which a methyl group replaces a hydrogen atom from benzene. Toluene is a common bulk chemical used worldwide as a solvent for many substances such as paints, coatings, inks, adhesives, and cleaning agents [1] and as a gasoline additive for improving octane ratings. Toluene is also useful in the benzene production process and to obtain several polymers used to manufacture synthetic materials (e.g., nylon and polyurethanes), dyes, cosmetic and pharmaceutical products, and several specialized organic chemicals [2]. Toluene is relatively soluble and volatile, so it contributes to both water and air pollution. When inhaled, it acts as a central nervous system suppressor and may be lethal after exposure for one hour at 1800 to $2000 \mathrm{ppm} v / v$ [3], and it may also cause chronic toxic effects at relatively low concentrations $[4,5]$. The American Conference of 
Governmental Industrial Hygienists (ACGIH) considers $20 \mathrm{ppm} v / v$ as a threshold limit value (TLV) for toluene exposure to avoid occupational risks [6].

According to the International Tanker Owners Pollution Federation [7], the amount of oil spilled since 1970 has greatly decreased. However, the critical point mentioned by the ITOPF itself is that the statistics for small leakages (i.e., lower than 7 tons) are not precise due to the difficulty of obtaining reliable information on these events. In this context, most of the toluene and related alkylbenzenes are released to the ecosystems from gasoline and other oil products being spilled from storage tanks and pipelines [1,7]. Since these are mostly underground leaks, they remain undetected for long periods, severely affecting soil and groundwater and posing a significant ecotoxicological risk to all biological systems.

As a strategy to reduce atmospheric pollution, many countries supplement gasoline with ethanol [8]. In Brazil, commercial gasoline is a blend composed of $27 \%$ of anhydrous ethanol [9]. Toluene and other alkylbenzenes that constitute gasoline are miscible in primary alcohols such as methanol and ethanol, which are also soluble in water [10]. Thereby, the presence of ethanol allows the solubilization of high levels of alkylbenzenes [11], which, added to the aging and poor conservation of fuel storage tanks, results in leaks where ethanol carries gasoline alkylbenzenes to the soil aqueous phase. This enables alkylbenzenes to move through the soil matrix, increasing the probability of polluting underground water bodies and aquifers [4]. Such an environmental impact has been dubbed as BTEX pollution because of the predominance of benzene, toluene, ethylbenzene, and xylene isomers.

Bioremediation is an alternative technology to the usually more expensive and less environmentally sustainable physicochemical cleanup methods for treating contaminated areas. It is essentially based on the ability of microorganisms to metabolize recalcitrant and/or toxic compounds, such as aromatic hydrocarbons, by transforming them into substances with lower molecular weights that are more polar and, eventually, by completely degrading them into $\mathrm{CO}_{2}$ and $\mathrm{H}_{2} \mathrm{O}$ [12].

Filamentous fungi and yeasts have been widely studied for degrading harmful organic compounds [13-16]. Several studies point to the presence of melanized fungi (also known as black yeasts or black fungi) in environments rich in aromatic hydrocarbons, such as air biofilters for treating volatile hydrocarbons, soil contaminated with oil and gasoline spills, wood treated with creosote, and a coal-distilled fraction rich in phenolic compounds used historically as a wood preservative for railway ties and telephone poles [17-21]. The extremophilic nature of black fungi, in association with the recurrent isolations of their representatives in hydrocarbon-related environments, suggests their potential use in bioremediation processes.

Black fungi are a polyphyletic group that harbors several polyextremotolerant and oligotrophic species. The most evident adaptation of these ascomycetes is the production and accumulation of melanin in their cell walls. Melanin is a dark pigment that protects the cell and aids survival under a wide range of adverse conditions related to radiation and oxidative stress exposure [22,23]. Besides melanin, black fungi are able to biosynthesize other protective compounds such as mycosporines and mycosporine-like amino acids (MAAs) [22].

Gueidan et al. [24] suggested that ancestors of black fungi were originally oligotrophic organisms living on rock surfaces or subsurfaces. Currently, it is known that oligotrophic fungi can also grow in anthropogenic habitats such as glass, silicon, organic surfaces, metals [25], creosoted railway sleepers [26], and on phenolic compounds and aromatic hydrocarbons [21].

Various microbial enrichment assays based on a solid state-like protocol that used perlite as inert support incubated under a toluene atmosphere have consistently yielded melanized strains from the Exophiala and Cladophialophora genera, such as E. xenobiotica, E. bergeri, C. immunda, and C. exuberans, that are able to grow with toluene as the sole source of carbon and energy $[18,20,27]$. One of these strains, Cladophialophora sp. T1, later identified as C. psammophila [28], was successfully used in the biofiltration of toluene using inert packing materials [29]. As reviewed by Prenafeta-Boldú et al. [16], the assimilative toluene 
metabolic pathway in melanized fungi involves essentially the activity of cytochrome P-450 monooxygenase enzymes, which perform the oxidation of the methyl group as the first step in toluene degradation. Genomic studies such as that by Teixeira et al. [30] described how cytochrome P-450 genes are important for metabolizing aromatic compounds and in the process of adaptation to extreme environments. Blasi et al. [31] highlighted that cytochrome P-450 is one of the most overexpressed protein domains of C. immunda growing in the presence of toluene.

Considering the lack of effective and useful methods for screening microorganisms with the ability to degrade volatile organic compounds (VOC) such as BTEX and given the relevance of the topic to mitigate hydrocarbon pollution, this study aimed (1) to isolate and characterize the black fungal community of different hydrocarbon-related environments and (2) to test a reliable and simple method to screen and select fungi for their potential application in the bioremediation of pollution with alkylbenzene hydrocarbons. The proposed methodology is based on the analysis of biomass production by fungal isolates cultivated in a mineral liquid medium and incubated under toluene atmospheres inside desiccators.

\section{Materials and Methods}

\subsection{Isolation and Preservation of Black Fungal Strains}

Black fungi were isolated from four different environments naturally and artificially associated with hydrocarbons (Table 1): contaminated soil, plant material, water samples, and insects.

Table 1. Melanized fungi isolation sources including their description, location and isolation methods applied.

\begin{tabular}{|c|c|c|c|}
\hline Substrate of Isolation & Description & $\begin{array}{l}\text { Locality (DMS * } \\
\text { Coordinates) }\end{array}$ & Isolation Method \\
\hline \multirow[t]{2}{*}{ Contaminated soil } & Soil from a garage shop & $\begin{array}{l}22^{\circ} 26^{\prime} 13^{\prime \prime} \mathrm{S} ; \\
47^{\circ} 34^{\prime} 4^{\prime \prime} \mathrm{W}\end{array}$ & Oi flotation \\
\hline & Land farming soil from an oil refinery & $\begin{array}{l}22^{\circ} 43^{\prime} 34^{\prime \prime} \mathrm{S} \\
47^{\circ} 8^{\prime} 7^{\prime \prime} \mathrm{W}\end{array}$ & Oil flotation \\
\hline Plant material & Bark fragments of Eucalyptus tereticornis & $\begin{array}{l}22^{\circ} 24^{\prime} 34.37^{\prime \prime} \mathrm{S} \\
47^{\circ} 32^{\prime} 28.98^{\prime \prime} \mathrm{W}\end{array}$ & Oil flotation \\
\hline Water samples & $\begin{array}{l}\text { Water samples from a river related to the activity } \\
\text { of an oil refinery }\end{array}$ & $\begin{array}{l}22^{\circ} 44^{\prime} 23^{\prime \prime} \mathrm{S} \\
47^{\circ} 07^{\prime} 40^{\prime \prime} \mathrm{W}\end{array}$ & Standard serial dilution \\
\hline Insects & Exoskeletons of gynes and drones of Attini ants & $\begin{array}{l}22^{\circ} 50^{\prime} 6^{\prime \prime} \mathrm{S} \\
48^{\circ} 26^{\prime} 1^{\prime \prime} \mathrm{W}\end{array}$ & Oil flotation/Agar walk \\
\hline
\end{tabular}

* DMS-Degrees, Minutes and Seconds.

Three different enrichment and/or isolation techniques were applied on these four sample categories:

(a) Oil flotation technique: This isolation method is known to be highly selective for hydrophobic fungi such as black yeasts [32]. Soil samples were taken from a garage shop (city of Rio Claro, São Paulo, Brazil) contaminated with motor oil from vehicles and from land farming soil from an oil refinery (city of Paulínia, São Paulo, Brazil). This method was also applied on bark fragments of Eucalyptus tereticornis and exoskeletons of gynes and drones (winged females and males of leaf-cutting ants) of Atta capiguara and Atta laevigata obtained during the sexual reproduction period known as the "mating flight" (city of Botucatu, São Paulo, Brazil).

(b) Standard serial dilution method: Water samples from a river under the influence of an oil refinery (Atibaia River, São Paulo, Brazil) were processed according to the standard methods [33]. Fungi were isolated through serial dilutions of the samples, followed by plating on potato dextrose and Sabouraud agar (PDA and SA).

(c) Agar walk method: Living individuals of the previously mentioned winged females and males of leaf-cutting ants (Atta capiguara and Atta laevigata) were placed on malt 
yeast agar plates (MYA; peptic digest of animal tissue, $5.0 \mathrm{~g}$; yeast extract, $3.0 \mathrm{~g}$; malt extract, $3.0 \mathrm{~g}$; dextrose, $10.0 \mathrm{~g}$; agar, $20.0 \mathrm{~g}$ per liter of distilled water) added with cycloheximide (500.0 mg), chloramphenicol (200.0 mg), and streptomycin (200.0 mg), and were allowed to walk on the agar for one hour. Then they were removed, and the plates were incubated at $25{ }^{\circ} \mathrm{C}$ until the emergence of the black colonies.

Melanized fungal colonies were purified by subsequent transfers to new agar plates and preserved in slants containing 2\% malt agar (MA; malt extract, $20.0 \mathrm{~g}$; agar, $20.0 \mathrm{~g}$ per liter of distilled water) maintained at $4{ }^{\circ} \mathrm{C}$ and by the ultra-freezing technique at $-80{ }^{\circ} \mathrm{C}$. For this purpose, cultures were grown in $2.0 \mathrm{~mL}$ microtubes containing $500 \mu \mathrm{L}$ of a $2 \%$ malt broth (malt extract, $20.0 \mathrm{~g}$ per liter of distilled water) for three to five days. Then, $500 \mu \mathrm{L}$ of a sterile $20 \%$ glycerol solution and sterile glass beads ( $4 \mathrm{~mm}$ to $6 \mathrm{~mm}$ ) were added to the microtubes and mixed manually. The tubes were placed into freezers at $-20^{\circ} \mathrm{C}$ overnight and then transferred to ultra-freezers at $-80^{\circ} \mathrm{C}$.

\subsection{Morphological Analysis}

Filamentous black filamentous fungi were grown on $2 \%$ MA or PDA, while black yeasts were grown on SA. Incubations were performed at $25{ }^{\circ} \mathrm{C}$ for five to 10 days. The macroscopic analysis was carried out using a stereomicroscope, and the microscopic analysis was performed by the assembly of glass slides with cotton blue dye.

\subsection{Molecular Identification}

Genomic DNA was obtained following the modified extraction protocol by Möller et al. [34] using cetyltrimethylammonium bromide (CTAB). The ITS (Internal Transcribed Spacer) region of the ribosomal DNA was amplified using primers V9G and LS266 [35] or ITS1 and ITS4 [36] according to the following program: $94{ }^{\circ} \mathrm{C}$ for $3 \mathrm{~min}$ followed by 30 cycles at $94{ }^{\circ} \mathrm{C}$ for $30 \mathrm{~s}, 55^{\circ} \mathrm{C}$ for $30 \mathrm{~s}, 72{ }^{\circ} \mathrm{C}$ for $1 \mathrm{~min}$, and $10{ }^{\circ} \mathrm{C}$ forever. Amplicons were purified with the GFX PCR DNA kit and gel band purification (GE Healthcare, Chalfont Saint Giles, UK). The sequencing reaction was performed with primers ITS1 and ITS4 [36] according to the following program: $95^{\circ} \mathrm{C}$ for $1 \mathrm{~min}$ followed by 28 cycles at $95^{\circ} \mathrm{C}$ for $15 \mathrm{~s}$, $50{ }^{\circ} \mathrm{C}$ for $45 \mathrm{~s}, 60{ }^{\circ} \mathrm{C}$ for $4 \mathrm{~min}$, and $4{ }^{\circ} \mathrm{C}$ forever. The sequencing reaction products were purified with the DYEnamicTM ET Dye Terminator Kit (GE Healthcare ${ }^{\circledR}$ ), following the manufacturer's instructions, then loaded into an ABI3139 automated sequencer (Applied BiosystemsTM). The sequences were aligned and edited using software BioEdit version 7.0.5.3 [37] and then compared to other sequences from the Genbank (NCBI-National Center for Biotechnology Information) by using the BLAST (Basic Local Alignment Search Tool) [38] and from the CBS-Fungal Biodiversity Centre (The Netherlands). Phylogenetic studies were carried out using software Clustal W [39] for sequence alignment and MEGA $X$ [40] for phylogenetic tree construction. The evolutionary history was inferred using the Maximum Likelihood method and the Kimura 2-parameter model [41].

\subsection{Biomass Production in Toluene Atmospheres}

The isolated strains of black fungi were grown on $2 \%$ MA for seven days. Test tubes $(10 \mathrm{~mL})$ previously weighted on an analytical balance were filled with $3 \mathrm{~mL}$ of a mineral medium composed of a macronutrient solution $\left(\mathrm{KH}_{2} \mathrm{PO}_{4}, 4.5 \mathrm{~g} ; \mathrm{K}_{2} \mathrm{HPO}_{4}, 0.5 \mathrm{~g} ; \mathrm{NH}_{4} \mathrm{Cl}\right.$, $2.0 \mathrm{~g} ; \mathrm{MgSO}_{4} \cdot 7 \mathrm{H}_{2} \mathrm{O}, 0.1 \mathrm{~g}$; distilled water, $1000 \mathrm{~mL}$ ) combined with a micronutrient solution $\left(\mathrm{FeCl}_{3}, 120 \mathrm{mg} ; \mathrm{H}_{3} \mathrm{BO}, 350 \mathrm{mg} ; \mathrm{CuSO}_{4} \cdot 5 \mathrm{H}_{2} \mathrm{O}, 10 \mathrm{mg} ; \mathrm{KI} 10 \mathrm{mg} ; \mathrm{MnSO}_{4} \cdot \mathrm{H}_{2} \mathrm{O}, 45 \mathrm{mg}\right.$; $\mathrm{Na}_{2} \mathrm{MoO}_{4} \cdot 2 \mathrm{H}_{2} \mathrm{O}, 20 \mathrm{mg} ; \mathrm{ZnSO}_{4} \cdot 7 \mathrm{H}_{2} \mathrm{O}, 75 \mathrm{mg} ; \mathrm{CoCl}_{2} \cdot 6 \mathrm{H}_{2} \mathrm{O}, 50 \mathrm{mg} ; \mathrm{AlK}\left(\mathrm{SO}_{4}\right) \cdot 12 \mathrm{H}_{2} \mathrm{O}$, $20 \mathrm{mg} ; \mathrm{CaCl}_{2} \cdot 2 \mathrm{H}_{2} \mathrm{O}, 13.25 \mathrm{~g} ; \mathrm{NaCl}, 10.0 \mathrm{~g}$; distilled water, $1000 \mathrm{~mL}$ ) in a proportion of $1000 \mathrm{~mL}: 2 \mathrm{~mL}$, respectively. The tubes were inoculated with a small amount of mycelia using an inoculation needle. The inoculum mass was undetectable by an analytical balance, and the mycelia were carefully collected to avoid contact with the agar culture medium. After the inoculation, the tubes were covered with perforated foil to allow gas exchange and incubated inside three desiccators ( $12 \mathrm{~L}$ of air volume each) under the following conditions: (1) positive growth control (GC), a mineral medium with $4 \%$ glucose as the carbon source; 
(2) toluene atmosphere at a high concentration (TH), a mineral medium and an atmosphere with toluene as the sole carbon source, provided by an uncovered flask containing $15 \mathrm{~mL}$ of pure toluene; (3) toluene atmosphere at low concentration (TL), a mineral medium and a toluene atmosphere created by placing a flask containing $15 \mathrm{~mL}$ of toluene and $15 \mathrm{~mL}$ of dibutyl phthalate (DBP); (4) negative control (NC), only a mineral medium to monitor the endogenous growth (Figure 1). According to the volatility, and the water/air and water/DBP partition coefficients of toluene at normal conditions [42], the initial estimated concentration of this compound at the TH and TL incubation conditions was 37,000 and $140 \mathrm{ppm} v / v$, respectively.

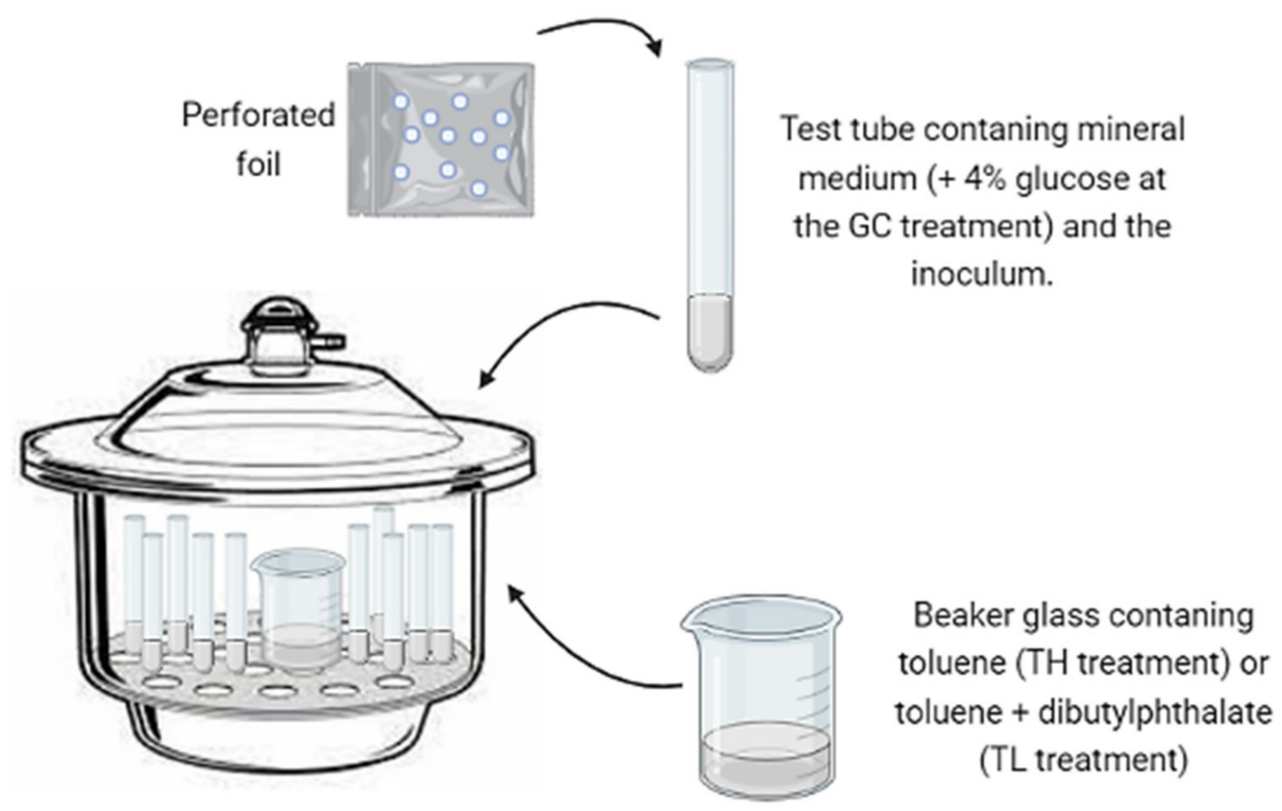

Figure 1. Schematic representation of the screening test to assess the potential of toluene assimilation by the melanized fungi. Test tubes containing fungal inoculum in a liquid medium were covered with perforated foil to allow gas exchange inside the desiccators. A beaker glass containing pure toluene or toluene diluted in dibutyl phthalate (DBP) were placed inside the desiccators in order to supply toluene as the sole source of carbon and energy via the gas phase at high and low concentrations, respectively.

The desiccators were closed and incubated at room temperature for 25 days. After the incubation, the biomass growth was assessed by measuring the dry weight. Test tubes were dried at $105{ }^{\circ} \mathrm{C}$ for $24 \mathrm{~h}$ then weighed on an analytical balance. The biomass values were obtained by calculating the difference between the final and initial weights of the tubes.

\subsection{Selection of Strains with Toluene Assimilation Potential}

For any given fungal strain, the harvested biomasses in terms of dry matter from the previously described incubations (GC, TH, LH, and NC) were used to calculate the growth ratios so to identify the strains that displayed the best growth potentials using toluene as the sole carbon source:

GC/NC ratio: amount of biomass produced on glucose (GC) divided by the biomass obtained with the negative control (NC). This ratio reflects how much more biomass is grown on a readily-used substrate versus the endogenous growth with no carbon source and indicates that a given strain is able to grow on a readily biodegradable substrate under the tested laboratory conditions.

$\mathrm{TH} / \mathrm{NC}$ ratio: amount of biomass produced in the toluene atmosphere (TH) divided by the biomass obtained with the negative control (NC). The higher this value is, the greater the likeliness of a given strain assimilating toluene at high concentrations. 
TL/NC ratio: biomass production in the presence of toluene and dibutyl phthalate (TL) divided by the biomass from the negative control (NC). The higher this value is, the greater the likeliness of a given strain using toluene at low concentrations. Comparisons between $\mathrm{TH} / \mathrm{NC}$ and TL/NC might indicate toluene toxicity.

Taking into account the ratios of biomass produced when supplying a carbon source (GC, TL, TH) in relation to the negative control (NC), the strains were ranked in four categories: category 1 , when the growth with a carbon source relative to the negative control (TG/NC, TH/NC, and TL/NC) is below 2; category 2, when the TG/NC, TH/NC, and TL/NC ratios range from 2 to 5; category 3, when the TG/NC, TH/NC, and TL/NC ratios range from 5 to 10; category 4 , when the TG/NC, TH/NC, and TL/NC ratios are greater than 10. Strains displaying TH/NC and TL/NC ratios in categories 3 and 4 were considered potential candidates for assimilative toluene biodegradation.

\subsection{Multivariate Ecological Analysis}

The multivariate analysis of the occurrence of fungal ribotype sequences was performed by means of the web-based biostatistics package Visualization and Analysis of Microbial Populations Structure (VAMPS) using the UNITE fungal genome database [43]. This software was also used for calculating the fungal species richness and biodiversity indices of the samples. A principal coordinate analysis (PCoA) analysis using the BrayCurtis distance metric was performed on the sequence data obtained from the isolated fungi, and the results were visualized in a 2D plot using the VAMPS package.

\section{Results and Discussion}

\subsection{Isolation and Identification}

A total of 200 strains were obtained from the isolation program carried out in hydrocarbon-related environments: contaminated soil, plant material, water samples, and insects. These strains were identified on morphological grounds, and identifications were confirmed through molecular means for 138 of them (Table S1). A total of 17 genera and 27 species were recognized by morphological and molecular analyses, belonging to the orders Chaetothyriales (86 strains), Pleosporales (52 strains), Cladosporiales (47), Capnodiales (5 strains), Microascales (1 strain), Xylariales (1 strain), and Venturiales (1 strain). The remaining seven strains were grouped as "melanized filamentous fungi" due to the lack of molecular data and distinctive phenotypical characteristics for an accurate identification.

Figure 2 presents the correspondence between the isolated species and their environments. Species richness estimators and biodiversity indices on the isolated fungi are summarized in Table 2. The highest number of isolates (over 40 strains) was obtained from samples of the hydrocarbon-associated soil and water using the oil flotation and the pour-plate methods, respectively. However, while all identified strains from the garage soil were associated with Exophiala dermatitidis (Chaetothyriales), the highest observed richness (25 species) and biodiversity indices were observed in the water samples under the influence of an oil refinery. The strains identified from land farming and bark samples were also primarily related to the Chaetothyriales, which comprised the highest number of strains identified in the present study. 

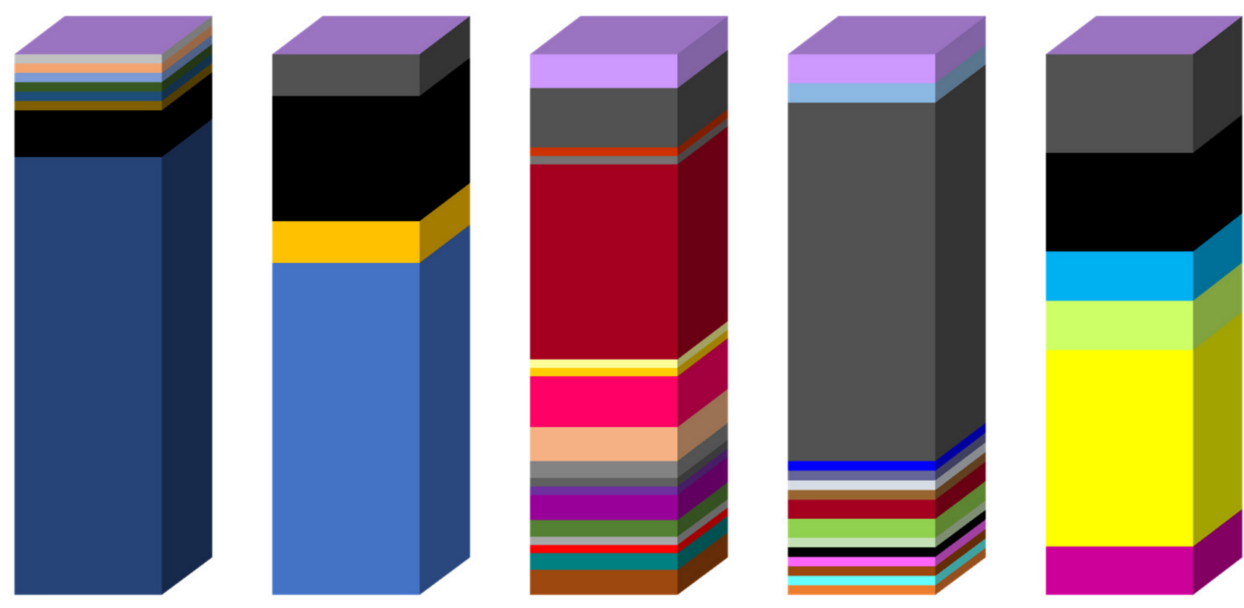

Garage soil

Eucalyptus bark

Water samples

Leaf-cutting ants

Landfarming soil

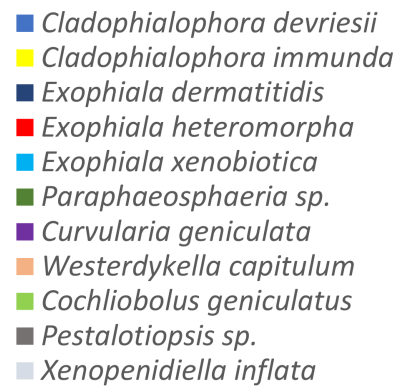

- Cladophialophora devriesii

- Exophiala dermatitidis

- Exophiala heteromorpha

- Exophiala xenobiotica

raphaeosphaeria sp.

Westerdykella capitulum

- Cochliobolus geniculatus

Xenopenidiella inflata
- Cladophialophora minourae

Cladophialophora sp.

- Exophiala attenuata

Exophiala bergeri

- Chaetothyriales species

- Phoma-like

Westerdykella dispersa

- Cochliobolus kusanoi

- Pleosporales species

Verruconis verruculosum

- Xenopenidiella laevigata

Figure 2. Relative abundance of strains obtained from the different hydrocarbon-related environments. Strains isolated from the garage soil, Eucalyptus bark, landfarming soil and leaf-cutting ants were obtained using the oil flotation technique (Satow et al., 2008). The ants were also submitted to the agar walk method. Strains recovered from the water samples were obtained by standard serial dilution according to Clesceri et al. (1998).

Table 2. Alpha diversity indexes of melanized fungi based on the sequenced isolated strains.

\begin{tabular}{cccccccc}
\hline Environmental Sample & $\begin{array}{c}\text { Isolation } \\
\text { Method }\end{array}$ & $\begin{array}{c}\text { No. of } \\
\text { Strains }\end{array}$ & $\begin{array}{c}\text { Observed } \\
\text { Richness }\end{array}$ & ACE ${ }^{\text {b }}$ & Chao1 & Shannon & Simpson \\
\hline Eucalyptus tereticornis bark & OF & 9 & 3 & 7.07143 & 4 & 0.98643 \\
Atta capiguara drone & OF, AW & 13 & 5 & 20.7037 & 11 & 1.50588 & 0.47037 \\
Atta laevigata drone & AW & 11 & 4 & 7.22469 & 4.5 & 1.49111 & 0.54545 \\
Garage soil & OF & 47 & 1 & 1 & 1 & 0 & 0 \\
Atta capiguara gyne & OF, AW & 7 & 2 & 3.11111 & 2 & 0.59167 & 0.2449 \\
Atta laevigata gyne & AW & 4 & 4 & error & 10 & 2 & 0.75 \\
Landfarming soil & OF & 7 & 4 & 5.78667 & 4.5 & 1.84237 & 0.69388 \\
Water sample & PP & 43 & 25 & 72.4482 & 47.6667 & 4.255 & 0.92699 \\
\hline
\end{tabular}

${ }^{a}$ OF: oil flotation; AW: agar walk; PP: pour plate. ${ }^{b}$ Abundance-based Coverage Estimator. 
Significant advances in the ecophysiology of Chaetothyrialean fungi have been achieved in the last decades [30]. This clade encompasses species that have been isolated recurrently from both clinical patients and hydrocarbon-rich environments. The connection between these two apparently distinct and highly-specific ecological traits is still a matter of discussion, and isolation campaigns such as that of the present study might provide deeper insights into the evolution of this group [44,45]. A genomic study by Moreno et al. [46] suggested an overlap between metabolic pathways used for nutrient acquisition in extreme environments and pathogenicity factors. Furthermore, it was found that black yeasts are able to undergo contractions and expansions of their genomes to increase survival according to changing environmental conditions [30,47]. Ant domatia-associated fungal species present smaller genomes than other related species in the Chaetothyriales, which might occur due to the specialized symbiosis with the insects [47]. Three genera belonging to the Herpotrichiellaceae family (Chaetothyriales) were identified among the isolates: Cladophialophora, Rhinocladiella, and Exophiala. A phylogenetic analysis carried out with sequences of the representative species of these three genera is shown in Figure S1.

Cladophialophora is a monophyletic genus that comprises the bantiana and carrionii clades $[30,48]$. Their representatives are common human pathogens, but non-virulent environmental strains have also been reported, such as C. yegresii [49], C. hostae, C. proteae, and C. scillae [50], C. pseudocarrionii [51], C. lanosa [52], and C. psammophila [28]. In this study, the species $C$. devriesii, C. mycetomatis, C. chaetospira, C. minourae, and C. immunda were identified. Although commonly described as a human pathogenic black yeast, strains of $C$. devriesii have also been isolated from environmental samples [48], as found in this study with the eight strains from this species obtained from E. tereticornis bark. It is known that this evergreen tree is rich in natural resins that contain volatile phenolic compounds and hydrocarbons [53,54]. It is important to highlight that this is the first report of $C$. devriesii from Eucalyptus.

Cladophialophora mycetomatis, also found in this study, is an uncommon species originally described from the human foot after trauma with the Opuntia spine (Cactaceae) in Mexico. To date, only two publications reported its isolation: Badali et al. [48], who described the species working with strains CBS 122,637 (clinical) and CBS 454.82 (environmental), and Nascimento et al. [27], who described the isolation of this species from babassu coconut shells. In this study, one strain of $C$. mycetomatis was obtained from the body of an A. laevigata drone. This is the first report of this black yeast in insects and, in particular, in leaf-cutting ants of the Attini tribe. Despite the first report from a human mycetoma, only environmental strains have been obtained since then, with no disease association.

Napolitano and Juaréz [55] were the first to suggest the use of hydrocarbons from the cuticle of insects as the sole carbon source for the growth of entomopathogenic fungi on Triatoma infestans. Regarding the black fungi, several authors concluded the existence of a straight relationship between their presence and the availability of hydrocarbons as a carbon source $[17,18,20]$. Attili-Angelis et al. [56] described two new species of Phialophora associated with Atta spp. and addressed questions on the diversity of ant-associated Chaetothyriales and their ecological aspects. A correlation of the hydrocarbons present in the insect cuticle with the occurrence of these fungi on the ant exoskeleton was suggested, thus reaffirming the hypothesis that these molecules are a potential key for survival in this environment. In the present study, one strain of C. chaetospira, originally described as a saprophytic species [48], was isolated from ants (Figure 2).

Landfarming soil is an environment rich in petroleum hydrocarbons that receives specific management aiming at the removal of these pollutants. From these samples, one strain of $C$. minoure and four of $C$. immunda were isolated. The first is a saprophytic fungus occurring on plant debris [48] and not commonly associated with hydrocarboncontaminated environments, unlike $C$. immunda, as its own name suggests an association with pollution [48]. In fact, toluene assimilation in this later fungus has been studied at the transcriptomic level [31]. 
A total of 57 strains were identified as Exophiala, with the representative species being E. dermatitidis (47), E. spinifera (4), E. attenuata (2), E. bergeri (1), E. heteromorpha (1), E. alcalophila (1), and E. xenobiotica (1). All the E. dermatitidis strains were isolated from the garage soil (Figure 2), indicating a high selectivity of the substrate and adaptation of the species to petroleum hydrocarbons. This species is related to human infections, but Sudhadham et al. [57] pointed out that birds, frugivorous bat feces, and fruits in tropical environments might be its environmental origin. The authors suggested that the entry into the human habitat came from the ingestion of wild fruits carrying the propagules of the species.

Exophiala alcalophila, E. heteromorpha, E. attenuata, and three of the four E. spinifera strains were obtained from the water samples (Figure 2), indicating a higher diversity of the genus in this environment. The last strain of E. spinifera and the single strain of $E$. bergeri were isolated from the leaf-cutting ants, while E. xenobiotica was recovered from the landfarming soil (Figure 2). The Exophiala genus is divided into several clades [58]. Exophiala heteromorpha is grouped in the dermatitidis clade, while E. xenobiotica and E. bergeri belong to the spinifera clade. These two clades contain the main lineages recognized as human pathogens, except for E. xenobiotica, originally isolated from sites contaminated with aromatic hydrocarbons [17]. No records involving E. attenuata, a representative of the mesophila clade, and E. alcalophila, which belongs to the alcalophila clade, with hydrocarbonassociated environments were found in the literature.

Two strains were identified as belonging to the Rhinocladiella genus, one of R. atrovirens and the other of $R$. similis, which are closely-related species. The Rhinocladiella genus is a synanamorph of Exophiala, i.e., both anamorphic species can occur at the same teleomorph. Del Palacio-Hernanz et al. [59] described the pathogenic nature of R. atrovirens; however, recent studies have been published where the species is placed as a saprotroph in the decomposition of pine wood [60,61].

The extremotolerance of melanized fungi is unquestionable. Ruibal et al. [62] isolated melanized fungi, including representatives of the Chaetothyriales order, from rock surfaces, where extreme adverse conditions such as high exposure to solar radiation and temperature, low nutrient availability, high electrolyte concentration, and low relative humidity are common. Besides the inhospitable rock surfaces, hydrocarbon-related environments such as sites contaminated with oil and its byproducts and creosote-treated wood are a great source for the isolation of these fungi [32,63], but they may also be found in unpolluted sites such as soil and vegetal debris [64]. Therefore, the general idea of their pathogenic nature must be revised, and biohazards must be assessed carefully for every new Chaetothyrialean species that displays a biotechnological potential.

The recurrent isolation of these fungi from environmental samples naturally or artificially exposed to hydrocarbons and related substrates corroborates the hypothesis of ecological dualities. This argues that strains isolated from the environment but identified as pathogenic and/or opportunistic due to a high genetic similarity might have an ecological role not related to virulence. That is, ecological niches between clinical and environmental strains related to hydrocarbons would be clearly differentiated, and the later strains would not cause infections [28].

The order Pleosporales presented the second largest number of representatives (52), isolated from all substrates (Figure 2). Pleosporales encompass a quarter of the Dothideomycetes class representatives, being the largest of its orders [65]. Pleosporalean species may occur in several habitats as epiphytes, endophytes, parasites of leaves and stems, or hyperparasites of fungi or insects, and in association with lichens or saprobes [66]. Reports of opportunistic strains are rare, which favors the exploration of their biotechnological potential, including their xenobiotic degradation capacity, which is still poorly studied in this group.

Most of the Pleosporalean strains identified in this study (44 strains out of 52) were isolated from water samples from the river under the influence of an oil refinery (Figure 2), and the eight remaining strains were obtained from the exoskeleton of leaf-cutting ants. 
Fungal metabolic diversity is quite significant, and the presence of alternative carbon sources that might also be toxic, such as the hydrocarbons present in these environments, could act as triggers to activate biodegradation pathways linked to detoxification and even assimilatory metabolism.

The Pleosporales anamorphs are mostly coelomycetes, but they may also be hyphomycetes. Phoma and its relatives are the most common anamorphs [66]. Boerema et al. [67] proposed a morphology-based classification of Phoma into nine sections: Phoma, Heterospora, Macrospora, Paraphoma, Peyronellaea, Phyllostictoides, Pilosa, Plenodomus, and Sclerophomella, which are precisely described in the "Phoma Identification Manual" [68]. The manual contains 223 descriptions of specific and infra-specific taxa and over 1000 synonyms in other coelomycetes genera [69]. Currently, the phylogenetic analysis of Phoma and its relatives shows the existence of several families, indicating the polyphyly of several genera and making the identification of representatives of this group more consistent [66]. In this study, 27 Pleosporalean strains were identified belonging to the genera Westerdykella (6), Microsphaeropsis (6) Cochliobolus (3), Curvularia (2), Paraphaeosphaeria (2), Epicoccum (1), Didymella (3), Pithomyces-like (1), and Phoma-like (3) (Figure 2; Figure S2). The 25 remaining strains were characterized as Pleosporales representatives by their morphologies. The absence of morphological characteristics (sterile colonies) and the low resolution of the DNA sequences hampered the genus/species-level identification.

Six strains were identified as Westerdykella (Sporormiaceae), including W. capitulum (4) and $W$. dispersa (2). The genus includes ubiquitous species occurring in manure as endophytes or in soil as saprophytes [70]. Cochliobolus kusanoi (1) and C. geniculatus (2) were isolated from water samples and the bodies of an A. capiguara drone and an A. laevigata gyne, respectively. Two Curvularia strains, namely C. platzii and C. geniculata, were also obtained from the water samples. The presence of Cochliobolus and its anamorphs Curvularia and Bipolaris had already been reported in Attini ants [71]. The three genera are members of the Pleosporaceae family and form a complex with well-known phytopathogenic species, especially of the Poaceae family (grass). Also, the Pithomyces genus is found in this family. One strain was morphologically identified as Pithomyces-like, a cosmopolitan genus found in soil and debris [72].

Six strains recovered from the water samples were identified as Microsphaeropsis arundinis, a member of the Montagnulaceae family. Alves et al. [73] described this species as an endophyte and ubiquitous. Costa et al. [74] reported its common presence in the mycobiota of Brazilian mangrove plants on the northeastern coast. Luo et al. [75] observed the production of specific sesquiterpenes by this species, referred to as "arundinols". From the same family, two strains of Paraphaeosphaeria sp. were isolated from the same substrate.

Didymella glomerata was the representative of the Didymellaceae family, having been isolated from the water samples in this study. As with most of the Pleosporales, this species has been obtained for a long time from senescent leaves of deciduous trees [76,77]. Three other strains from the same substrate were morphologically identified as Phoma-like due to the presence of pigmented conidia, unlike what occurs with Phoma representatives. Molecular data from the ribosomal DNA did not clearly define the specific identification of the strains.

A total of 52 isolates were identified as representatives of the orders Cladosporiales (47) and Capnodiales (5). The Cladosporiales order was recently proposed, as well as the family Cladosporiaceae, in which it is included [78]. Members of Cladosporiales were previously treated as Capnodiales. Both orders belong to the Dothideomycetidae subclass and comprises epiphytes, endophytes, and saprophytes species, occurring in association with algae (forming lichens) or as parasites of fungi and animals [78,79]. In this study, all the Cladosporiales isolates belong to the Cladosporium genus. The identification to specific level was not possible since the ITS sequencing was not enough to define all species. This is a very complex and heterogeneous genus comprising hyphomycetes with a typical recognizable coronate scar type. The morphological differentiation among species is often confusing, so molecular tools are of great importance. However, even using DNA 
sequencing, the comparison of sequences from only one genic region may not be reliable enough for precise identification. Data from a phylogenetic analysis with some strains show that the species are allocated at the cladosporioides complex [80] within the Cladosporium genus (Figure S2).

Among the 47 Cladosporium strains, 37 were obtained from the exoskeleton of leafcutting ants. Rodrigues et al. [81,82] previously reported the presence of this genus on ants. Pagnocca et al. [83] also found the predominance of Cladosporium strains from Atta gynes, pointing out that these insects could act on its dispersion, but no interactions were shown between this genus and the symbiont fungus cultivated by the ants.

The other 10 Cladosporium strains were isolated from the water samples under the influence of an oil refinery (7), from the landfarming soil (2), and one strain from E. tereticornis bark (Figure 2). Cladosporium conidia are the most common fungal component isolated from the air [84]. It is a cosmopolitan genus with species found in all kinds of plants, debris, soil, food, paints, textiles, and any other organic matter [85]. Considering the substrates studied herein, its occurrence was quite expected. The highest number of Cladosporium species are clustered in the cladosporioides complex, and several studies report their common isolation from different environments [86-88], explaining the prevalence of species from this complex in the studied samples.

Representatives of the Xenopenidiella genus were obtained as members of the Capnodiales order. Only three strains were recovered from the cuticle of A. laevigata leaf-cutting ants (Figure 2). Xenopenidiella formica and X. inflata were isolated from drones, while X. laevigata was isolated from a gyne. The genus, very similar to Penidiella, was described by Quaedvlieg et al. [89] as a saprophytic on leaf litter. The presence of Xenopenidiella species associated with the ants is possibly related to their habit of foraging fresh plant matter into the nest. The molecular analysis carried in this study revealed that these three strains could represent novelties to science. Their description was made by Duarte et al. [90].

Besides these orders, one strain of Pseudallescheria boydii (from water samplesMicroascales), one of Pestalotiopsis sp. (from water samples-Xylariales), and one of Verruconis verruculosum (drone of $A$. laevigata-Venturiales) were also isolated. The Microascales order includes saprophytic fungi commonly found in soil [91]. Pseudallescheria boydii is originally a saprophyte often isolated from agricultural soils and contaminated water; however, it has been reported from clinical samples, especially in immunosuppressed patients [92]. It is also found in hydrocarbon-related environments such as diesel pipelines and soil with oil residues, being able to degrade oil and its byproducts besides biodiesel [93-96]. Xylariales is a monophyletic order with more than 92 genera [97]. The Pestalotiopsis genus is widely spread in tropical and temperate regions and is an important plant pathogen. More than 235 species are described in this genus, and they are named according to the hosts they are associated with [98,99]. Venturiales and the Sympoventuriaceae family were described by Zhang et al. [66] in order to accommodate members of the Venturiaceae family traditionally grouped with Pleosporales. Verruconis and Ochroconis are related genera that belong to the Sympoventuriaceae family. Verruconis spp. are thermophilic, while Ochroconis spp. are mesophylic. Both genera contain clinical and environmental strains reported in the literature [100], corroborating the ecological duality already mentioned for melanized fungi.

\subsection{Fungal Community Structure}

The similarities between the community structure of the isolated black fungi in the studied samples were analyzed by multivariate PCoA. The total variance explained by the three first axes amounted to $70.983 \%$, and sample scores were grouped around the main cluster formed by those fungal communities obtained from the cuticle of ants (Figure 3). Such relatively similar fungal communities from ants were observed even though were isolated from different individuals and species (drones and gynes of $A$. capiguara and A. laevigata) using two very distinct isolation methods (oil flotation and agar walk). All insect samples had in common the predominance of Cladosporium spp., but some other 
isolates were shared among at least two individuals (Xenopenidiella sp. and Pleosporales sp.) or were single isolations (Exophiala and Cladophialophora spp., and Verruconis sp.). The cuticle of these ants is a highly hydrophobic environment that also contains volatile pheromones used for communication by these social insects. These signaling molecules include aromatic compounds (e.g., pyrrole and pyrazine) and long-chain hydrocarbons (alkanes and alkenes) [101]. The black fungi isolated from the landfarming soil with a history of oil pollution yielded a very limited number of strains, some of which had previously been recognized as hydrocarbon degraders (e.g., C. immunda and E. xenobiotica; Figure 2; Table S1).
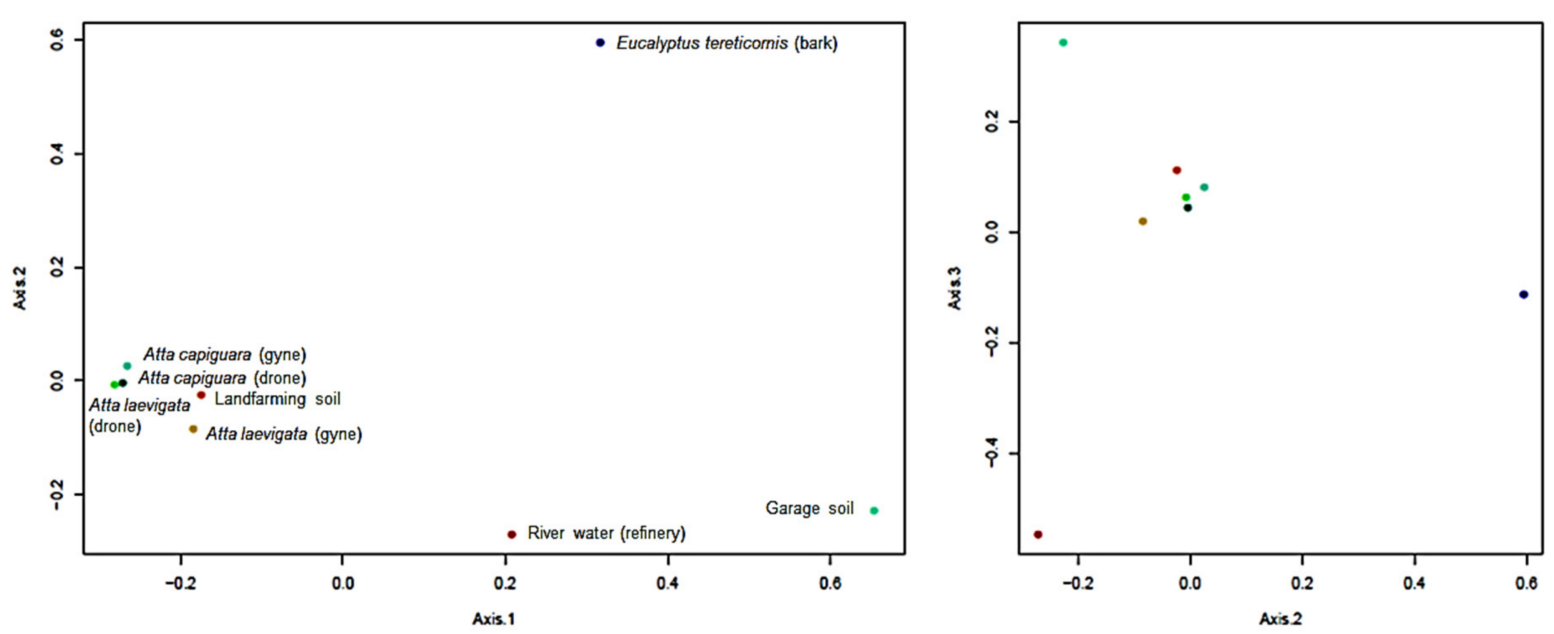

Figure 3. Two-dimensional (2D) plots of a principal coordinate analysis (PCoA, Bray-Curtis distance) on the relative abundance of melanized strains isolated from different hydrocarbon-associated environments, based on the analysis of their ITS rDNA sequences (Encompassed variance: $32.86 \%$ in Axis 1, 20.40\% in Axis 2, and $17.72 \%$ in Axis 3).

Conversely, the community structure of melanized fungi from the garage soil, river waters, and bark were clearly distinct from each other and in relation to those from insects. Strains from the garage soil were obtained by the oil flotation technique, and practically all of them were identified as E. dermatitidis. Apparently, the profile of oilderived hydrocarbons in this environment exerted a very selective pressure on fungal biodiversity, favoring this particular taxon. A possible reason for this is the accumulation of motor oil, lubrication additives, and toxic metals that might restrict microbial growth to tolerant species. It could also be that the selectivity of the oil flotation technique resulted in a positive bias towards the isolation of this particular species; however, the oil flotation was also used in other samples (landfarming soil, bark, and ants) and gave very different results in terms of biodiversity and identity of predominant species. Similar to the garage soil, fungi from Eucalyptus bark were strongly dominated by a single species, in this case, C. devriesii (Figure 3). The bark of E. tericornis is highly hydrophobic and contains several hydrocarbons, which are mainly present as resins [53,54].

Interestingly, the water samples related to the refinery were characterized by the highest melanized fungal biodiversity. This is to be expected when using the less-specific pour-plate methods, but the isolation from water samples of a large number of melanized fungi, which in principle grow relatively slowly on culture media and have generally been associated with solid surfaces (rocks, bark, cuticle, etc.), is quite puzzling. Thus, it is worth examining whether or not melanized fungi could be used as bioindicators of present or past pollution events with petroleum hydrocarbons in water bodies.

\subsection{Growth Specificity Experiments}

This test aimed to select fungi able to produce biomass in a selective environment containing toluene as the sole source of carbon and energy at high and low concentrations. 
The biomass yield values and ratios obtained with the different growth conditions tested are compiled in Table S1, but a subset with the most promising strains in terms of growth in the presence of toluene has been summarized in Table 3. The analysis showed that growth on glucose usually yielded more biomass than on toluene because the former is a readily available sugar (the GC/NC ratio is generally greater than TL/NC or TH/NC; Table 2). In most cases, when there was significant growth on toluene, the TL/NC ratio was the same or higher than the $\mathrm{TH} / \mathrm{NC}$ ratio, which points to the toxicity of this compound at air saturation for certain isolates. Although toluene is responsible for extensive cellular damage, mainly at the membrane, the data showed that several of the isolated strains were able to tolerate and even grow on toluene at air-saturation conditions.

Table 3. Selected strains from the desiccator test according to the growth ratios calculated using the biomass produced by the melanized fungi when glucose, toluene, or no carbon source was offered. The selection includes only strains that more than quintupled the biomass production compared to the endogenous growth (NC) when toluene was supplied as the only carbon source (TL and TH).

\begin{tabular}{|c|c|c|c|c|c|c|c|c|c|}
\hline \multicolumn{3}{|c|}{ Data on the Strains } & \multicolumn{4}{|c|}{ Biomass (mg) } & \multicolumn{3}{|c|}{ Ratios } \\
\hline ID & Species & Substrate of Isolation & GC & NC & TH & TL & $\mathrm{GC} / \mathrm{NC}$ & TH/NC & TL/NC \\
\hline A55 & Westerdykella dispersa & Water samples & 81.9 & 1.4 & 14.5 & 17.9 & 58.5 & 10.4 & 12.8 \\
\hline $\mathrm{A} 234$ & Pestalotiopsis sp. & Water samples & 38.8 & 0.3 & 4.4 & 4.1 & 129.3 & 14.7 & 13.7 \\
\hline N34 & Cladosporium sp. & Atta capiguara drone & 36.9 & 0.4 & 8.1 & 4.2 & 92.3 & 20.3 & 10.5 \\
\hline $\mathrm{F} 21$ & $\begin{array}{l}\text { Melanized } \\
\text { filamentous fungus }\end{array}$ & Atta capiguara drone & 82.6 & 1.5 & 14.8 & 10.3 & 55.1 & 9.9 & 6.9 \\
\hline D4 & $\begin{array}{c}\text { Cladophialophora } \\
\text { devriesii }\end{array}$ & $\begin{array}{c}\text { Eucalyptus tereticornis } \\
\text { bark }\end{array}$ & 86.4 & 1.4 & 17.0 & 6.6 & 61.7 & 12.1 & 4.7 \\
\hline D5 & $\begin{array}{c}\text { Cladophialophora } \\
\text { devriesii }\end{array}$ & $\begin{array}{c}\text { Eucalyptus tereticornis } \\
\text { bark }\end{array}$ & 81.7 & 1.6 & 4.4 & 18.1 & 51.1 & 2.8 & 11.3 \\
\hline D15 & Chaetothyriales sp. & $\begin{array}{c}\text { Eucalyptus tereticornis } \\
\text { bark }\end{array}$ & 90.7 & 1.8 & 18.9 & 2.4 & 50.4 & 10.5 & 1.3 \\
\hline D31 & Exophiala dermatitidis & $\begin{array}{l}\text { Soil from machine } \\
\text { shop }\end{array}$ & 76.8 & 1.8 & 17.5 & 4.3 & 42.7 & 9.7 & 2.4 \\
\hline D153 & Exophiala dermatitidis & $\begin{array}{l}\text { Soil from machine } \\
\text { shop }\end{array}$ & 87.2 & 2.7 & 16.9 & 18.1 & 32.3 & 6.3 & 6.7 \\
\hline D180 & Exophiala dermatitis & $\begin{array}{l}\text { Soil from machine } \\
\text { shop }\end{array}$ & 27.3 & 2.0 & 3.0 & 34.5 & 13.7 & 1.5 & 17.3 \\
\hline A126 & Pleosporales sp. & Water samples & 5.9 & 1.2 & 6.1 & 6.6 & 4.9 & 5.1 & 5.5 \\
\hline A304 & $\begin{array}{l}\text { Melanized } \\
\text { filamentous fungus }\end{array}$ & Water samples & 67.8 & 1.6 & 4.7 & 15.9 & 42.4 & 2.9 & 9.9 \\
\hline A393 & Pleosporales sp. & Water samples & 22.5 & 1.8 & 17.7 & 6.8 & 12.5 & 9.8 & 3.8 \\
\hline N21 & Cladosporium sp. & Atta capiguara drone & 25.7 & 3.0 & 19.0 & 18.3 & 8.6 & 6.3 & 6.1 \\
\hline N85 & Cladosporium sp. & Atta laevigata drone & 21.4 & 2.4 & 16.5 & 17.3 & 8.9 & 6.9 & 7.2 \\
\hline N92 & Cladosporium sp. & Atta capiguara gyne & 34.6 & 2.7 & 16.6 & 17.5 & 12.8 & 6.1 & 6.5 \\
\hline N101 & Cladosporium sp. & Atta laevigata drone & 49.7 & 2.2 & 17.9 & 17.1 & 22.6 & 8.1 & 7.8 \\
\hline F18 & Cladosporium sp. & Atta capiguara drone & 31.2 & 3.1 & 17.5 & 17.3 & 10.1 & 5.6 & 5.6 \\
\hline NR7 & Pleosporales sp. & Water samples & 81.3 & 1.5 & 16.6 & 4.8 & 54.2 & 11.1 & 3.2 \\
\hline
\end{tabular}

$\mathrm{GC}=$ positive control (glucose); $\mathrm{NC}=$ negative control; $\mathrm{TH}=$ toluene atmosphere at high concentration; $\mathrm{TL}=$ toluene atmosphere at low concentration.

Concerning the candidate strains for toluene assimilation (Table 3), W. dispersa A55, Pestalotiopsis sp. A234, and Cladosporium sp. N34 deserve special attention due to their high biomass production ratio relative to the endogenous control, with both high and low toluene concentrations (TH/NC and TL/NC). The strains C. devriesii D4, Chaetothyriales sp. D15, and Pleosporales sp. NR7 were only able to increase more than tenfold the biomass production compared to $\mathrm{NC}$ at high toluene concentrations (TH). On the other hand, the Chaetothyrialean strains $C$ devriesii D5 and E. dermatitidis D180 exhibited the same pattern but only at low toluene concentrations (TL). All the other Cladosporium sp. strains (N21, N85, N92, N101, and F18), E. dermatitidis D153, and the melanized filamentous fungus F21 
displayed moderate $\mathrm{TL} / \mathrm{NC}$ and $\mathrm{TH} / \mathrm{NC}$ ratios and are also promising strains for toluene assimilation. Finally, the TH/NC ratio for the strains E. dermatitidis D31 and Pleosporales sp. A393 was close to 10, and the melanized filamentous fungus A304 showed a similar condition but at low toluene concentrations (TL/NC).

Interestingly, three orders are predominant among the 19 selected strains: 5 representatives of Pleosporales, 6 Cladosporiales (all Cladosporium spp.), 6 Chaetothyriales, and 2 unidentified melanized filamentous fungi. The literature reports hydrocarbon biodegradation as a common characteristic of Chaetothyrialean fungi, especially in the derived Herpotrichiellaceae family, which includes the Cladophialophora and Exophiala genera. Therefore, it was expected that a higher number of representatives of this group would be found as potential toluene degraders. All selected strains belonging to the Pleosporales order were obtained from water samples under the influence of an oil refinery, while Cladosporium sp. strains (Cladosporiales) were isolated from ant exoskeletons. It is quite unexpected that the members of the Chaetothyriales that were found among the potential toluene-growing strains (Table 3) were the species Exophiala dermatitidis and Cladophialophora devriesii, while strains originally related to hydrocarbon-associated environments such as E. xenobiotica and C. immunda, for example, did not show significant growth on toluene. Reliable screening methodologies for evaluating the microbial assimilation potential of volatile substrates such as toluene are scarce. Several drawbacks have been identified, such as the difficulties to deal with volatile substrates that might diffuse through a wide range of plastic materials and the oligotrophic nature of many microorganisms so that they can grow on agar impurities [102].

Blasi et al. [103] designed a high-throughput microtiter plate assay method for screening the ability of 163 fungal strains from a culture collection to grow on different pollutants, including toluene provided through the gas phase in an enclosed desiccator containing a beaker filled with this compound. The assimilation of toluene was inferred upon the analysis of cell growth by taking optical density measurements at different times, and 25 strains were selected as positive for toluene growth on this basis. However, toluene assimilation could only be verified for two of these strains, belonging to C. immunda and E. mesophila, using chromatographic measurements of toluene biodegradation and carbon dioxide production.

This study provides an additional inexpensive and straightforward method for assessing the fungal potential for toluene assimilation of a collection of melanized fungi isolated from different hydrocarbon-related environments. In addition, the effect of the toluene concentration was tested by mixing it with dibutyl phthalate as a way to mitigate the toxicity of this compound. However, this attenuation was not needed for many strains, which were able to grow on toluene under saturated air/water conditions. It is well known that melanized fungi can survive and grow in extreme environments. They can deal with water and nutrient scarcity, low $\mathrm{pH}$, different kinds of radiation, and the presence of xenobiotics. This tolerance is associated with their conspicuous melanization. Melanins are complex molecules with uncommon physical and chemical properties that guarantee protection and adaptation to several stressful processes, including the presence of toxicants such as the BTEX.

In their review, Cordero et al. [23] presented several studies which confirm that microbial melanins can be very useful to reach a sustainable future, given that they can act on radioprotection, bioremediation of xenobiotics, and heavy-metal-polluted sites. The only sensitive issue regarding melanized microorganisms is the fact that melanin may be associated with microbial virulence. Species that are opportunistic and pathogenic to humans and other animals have been reported in this group. Therefore, it is necessary to consider all aspects of biosecurity, aiming to select the non-virulent strains.

A notorious result from this study is that there was considerable mycelial growth for several strains when no carbon source was offered (NC; Table S1). Dolatabadi et al. [104] reported this same condition for strains of E. xenobiotica and Phialophora americana isolated from oil-contaminated soil and tested for BTEX assimilation. Satow et al. [32] and 
Zhao et al. [20] reported the growth ability of melanized fungi under nutrient paucity conditions, highlighting the oligotrophic nature of these microorganisms that included oligocarbonotrophic traits. Since 1980, studies aiming at the characterization of the oligotroph nature presented by several fungal strains have been performed, and they indicate the ability of these microorganisms to remove the carbon necessary for their survival from inorganic sources, even from atmospheric $\mathrm{CO}_{2}$. According to Wainwright et al. [105], fungi can grow oligotrophically without apparent involvement of lysis and the use of preformed hyphae. Parkinson et al. [106] found hyphae of Fusarium oxysporum growing oligotrophically without undergoing lysis, remaining intact and filled with cytoplasm from the inoculation point to the tips of actively growing hyphae. Zhdanova et al. [107] isolated melanized fungi in nuclear reactors and their cooling water. Dadachova et al. [108], working with fungi isolated from Chernobyl nuclear reactors, reported that they seemed to use their melanin to convert gamma radiation into chemical energy for their development. Onofri et al. [109] discussed the survivability of these microorganisms in conditions analogous to the extraterrestrial environment.

Fungal degradation of xenobiotics such as toluene involves the presence of specific metabolic pathways that act on the aromatic ring cleavage and its conversion into assimilable compounds as sources of carbon and energy $[19,31]$. The study of melanized fungi as potential aromatic biodegraders has intensified in the last few decades because of their historical potential and the recurrent isolation of their representatives from environments related to the presence of hydrocarbons. Results obtained in this study highlight the biodiversity of melanized fungi present in hydrocarbon-associated environments and their potential capacity for the assimilative biodegradation of toluene. Further studies will be performed with selected strains in order to confirm their capacity to grow on toluene and assess their potential uses in environmental biotechnology applications.

\section{Conclusions}

The findings of this study illustrate the biodiversity of melanized fungi that survive in different natural and anthropogenic hydrocarbon-rich environments, and also their capacity to tolerate and even grow on toluene, supplemented as the sole carbon and energy source at relatively low and high concentrations. This information might be useful for designing new bioindication tools on the hydrocarbon exposure of natural and anthropized environments. The isolated strain populations appeared to be rather specific from the studied environments and ranged from the lowest biodiversity in the garage ground spilled with motor oil, where all 47 isolated strains belonged to E. dermatitidis, a well-known opportunistic pathogen, to the high biodiversity of the refinery-impacted river, in which 25 distinct species were observed out of 43 isolated strains. The results also confirmed the preference of the Chaetothyriales for hydrocarbonaceous environments, and Exophiala spp. were isolated from all the studied samples. This genus contains several species that have been investigated thoroughly for the biofiltration of air polluted with volatile organic compounds, but that have also been isolated from clinical cases. The high tolerance of black fungi, well above that of most bacteria, to harsh and fluctuating environmental conditions makes them ideal catalysts for several bioremediation applications, but might also predispose them towards virulence. Interestingly, the most promising results for the potential of toluene assimilation in terms of biomass yield were obtained with species from the Pleosporales, Cladosporiales, and Xylariales, which are generally less biohazardous than those from the Chaetothyriales. The capacity of the newly isolated fungi to metabolize toluene as the sole source of carbon and energy needs to be verified by more precise growth experiments, but it might well be so that the range of hydrocarbonoclastic fungal species with biotechnological potential needs to be revised in the future.

Supplementary Materials: The following are available online at https: / www.mdpi.com/article / 10.3390/microorganisms9051008/s1, Table S1. The following table contains values of biomass production in milligrams (mg) for the 200 strains submitted to the toluene assimilation test in each treatment, growth ratios, as well as their identification and source. GC = biomass produced with 
glucose as the carbon source; $\mathrm{NC}=$ biomass produced in the absence of a carbon source; $\mathrm{TL}=$ toluene as the sole carbon source added with dibutyl phthalate; $\mathrm{TH}=$ toluene as the sole carbon source. Figure S1. Phylogenetic analysis using sequences of strains from the Chaetothyriales order. Highlighted strains are representatives obtained in this study. Accession numbers are presented before taxon names for sequences collected at the Genbank. TYPE = Type strain material. The evolutionary history was inferred using the Maximum Likelihood method and the Kimura 2-parameter model (Kimura, 1980). The percentage of trees in which the associated taxa clustered together is shown next to the branches. Initial trees for the heuristic search were obtained automatically by applying the Neighbor-Joining and BioNJ algorithms to a matrix of pairwise distances estimated using the Maximum Composite Likelihood (MCL) approach, then selecting the topology with the highest log-likelihood value. The tree is drawn to scale, with branch lengths measured in the number of substitutions per site. This analysis involved 71 nucleotide sequences. There were a total of 643 positions in the final dataset. Figure S2. Phylogenetic analysis using sequences of strains from the orders Cladosporiales and Pleosporales. Highlighted strains are representatives obtained in this study. Accession numbers are presented before taxon names for sequences collected at the Genbank. TYPE = Type strain material. The evolutionary history was inferred using the Maximum Likelihood method and the Kimura 2-parameter model (Kimura, 1980). The percentage of trees in which the associated taxa clustered together is shown next to the branches. Initial trees for the heuristic search were obtained automatically by applying the Neighbor-Joining and BioNJ algorithms to a matrix of pairwise distances estimated using the Maximum Composite Likelihood (MCL) approach, then selecting the topology with the highest log-likelihood value. The tree is drawn to scale, with branch lengths measured in the number of substitutions per site. This analysis involved 39 nucleotide sequences. There were a total of 606 positions in the final dataset.

Author Contributions: Conceptualization, D.A.d.A., F.X.P.-B. and N.C.B.; methodology, D.A.d.A., F.X.P.-B. and N.C.B.; investigation, N.C.B., A.A.O.; resources, D.A.d.A., F.C.P., F.X.P.-B., V.A.V.; data curation, N.C.B., D.A.d.A., F.X.P.-B.; writing-original draft preparation, N.C.B., D.A.d.A., F.X.P.B.; writing-review and editing, D.A.d.A., F.X.P.-B., F.C.P., V.A.V., A.A.O.; supervision, D.A.d.A.; funding acquisition, N.C.B., D.A.d.A., F.X.P.-B., F.C.P., V.A.V.; All authors have read and agreed to the published version of the manuscript.

Funding: This research was funded by the development agencies CNPQ, CAPES, and FAPESP (grant number 2013/01556-2), and was also supported by the Consolidated Research Group TERRA (grant number 2017 SGR 1290) and the CERCA Program/Generalitat de Catalunya. V.A.V. received fellowship from the National Council for Scientific and Technological Development (CNPq), Brazil. Project n. 312811/2018-7.

Institutional Review Board Statement: Not applicable.

Informed Consent Statement: Not applicable.

Data Availability Statement: Data are available in supplementary materials (Figures S1 and S2, Table S1).

Conflicts of Interest: The authors declare no conflict of interest.

\section{References}

1. Mitra, S.; Roy, P. BTEX: A Serious Ground-water Contaminant. Res. J. Environ. Sci. 2011, 5, 394-398. [CrossRef]

2. Environmental Protection Agency's (EPA). Toluene. Available online: https://www.epa.gov/sites/production/files/2016-09/ documents/toluene.pdf (accessed on 30 October 2020).

3. Hobara, T.; Okuda, M.; Gotoh, M.; Oki, K.; Segawa, H.; Kunitsugu, I. Estimation of the Lethal Toluene Concentration from the Accidental Death of Painting Workers. Ind. Health 2000, 38, 228-231. [CrossRef] [PubMed]

4. Melquiades, R.A.; Lobo, I.; Guedes, C.L.B.; Pinto, J.P. Análise de benzeno, tolueno, etilbenzeno e xilenos em solos por headspace e cromatografia gasosa/detector de ionização de chama. Semin. Ciências Exatas Tecnológicas Londrina 2006, 27, 113-120. [CrossRef]

5. Wilbur, S.M.A.; Bosh, S.B.S.U.S. Interaction Profile for: Benzene, Toluene, Ethylbenzene, and Xylenes (BTEX); Department of Health and Human Services Public Health Service Agency for Toxic Substances and Disease Registry: Atlanta, GA, USA, 2004.

6. Occupational Safety and Health Administration (OSHA). Toluene: Occupational Exposure Limits. 2012. Available online: https: / / www.osha.gov/toluene/occupational-exposure-limits (accessed on 30 October 2020).

7. ITOPF. Oil Tanker Spill Statistics. 2018. Available online: http://www.itopf.org/fileadmin/data/Documents/Company_Lit/ Oil_Spill_Stats_2018.pdf (accessed on 30 March 2019). 
8. Brito, N.N.; Zamora, P.P.; Neto, A.L.O.; De Battisti, A.; Paterniani, J.E.S.; Pelegrini, R.T. Utilização de fungos na remediação de efluentes industriais. In IV Fórum de Estudos Contábeis; Faculdades Integradas Claretianas: Rio Claro, SP, Brazil, 2002 ; pp. 18-22.

9. Brandão, L.F.P.; Suarez, P.A.Z. Determination of the alternative butanol/gasoline and butanol/diesel fuel blends heats of combustion by a heat-loss compensated semi-microcalorimeter. J. Therm. Anal. Calorim. 2018, 132, 1953-1960. [CrossRef]

10. Silva, R.L.B.; Barra, C.M.; Monteiro, T.C.N.; Brilhante, O.M. Estudo da contaminação de poços rasos por combustíveis orgânicos e possíveis conseqüências para a saúde pública no município de Itaguaí, Rio de Janeiro, Brasil. Cad. Saúde Públ. 2002, 18, $1599-1607$. [CrossRef]

11. CIMA-Conselho Interministerial do Açúcar e do Álcool. 2013. Available online: http://nxt.anp.gov.br/NXT/gateway. dll/leg/folder_resolucoes/resolucoes_cima /2013/rcima\%201\%20-\%202013.xml?f=templatesfn=document $\$-\$$ frame.htmfn= document $\$$-\$frame.htm3.0q=q=x=\$nc=9930. (accessed on 8 March 2018).

12. Alexander, M. Biodegradation and Bioremediation, 2nd ed.; Academic Press: New York, NY, USA, 1999.

13. Singh, H. Mycorremediation: Fungal Bioremediation; Wiley-Interscience, John Wiley \& Sons, Inc., Publication: Hoboken, NJ, USA, 2006.

14. Harms, H.; Schlosser, D.; Wick, L.Y. Untapped potential: Exploiting fungi in bioremediation of hazardous chemicals. Nat. Rev. Genet. 2011, 9, 177-192. [CrossRef]

15. Barrech, D.; Ali, I.; Tareen, M. A Review on Mycoremediation-The fungal bioremediation. Pure Appl. Biol. (PAB) 2018, 7, 343-348. [CrossRef]

16. Prenafeta-Boldú, F.X.; de Hoog, G.S.; Summerbell, R.C. Fungal Communities in Hydrocarbon Degradation. In Microbial Communities Utilizing Hydrocarbons and Lipids: Members, Metagenomics and Ecophysiology; McGenity, T.J., Ed.; Springer Nature Switzerland AG: Cham, Switzerland, 2019; pp. 1-36.

17. De Hoog, G.S.; Zeng, J.S.; Harrak, M.J.; Sutton, D.A. Exophiala xenobiotica sp. nov., an opportunistic black yeast inhabiting environments rich in hydrocarbons. Antonie Leeuwenhoek 2006, 90, 257-268. [CrossRef]

18. Prenafeta-Boldú, F.X.; Kuhn, A.; Luykx, D.M.; Anke, H.; van Groenestijn, J.W.; de Bont, J.A. Isolation and characterisation of fungi growing on volatile aromatic hydrocarbons as their sole carbon and energy source. Mycol. Res. 2001, 105, 477-484. [CrossRef]

19. Prenafeta-Boldú, F.X.; Summerbell, R.; De Hoog, G.S. Fungi growing on aromatic hydrocarbons: Biotechnology's unex-pected encounter with biohazard. FEMS Microbiol Rev. 2006, 30, 109-130. [CrossRef]

20. Zhao, J.; Zeng, J.; De Hoog, G.S.; Attili-Angelis, D.; Prenafeta-Boldú, F.X. Isolation and Identification of Black Yeasts by Enrichment on Atmospheres of Monoaromatic Hydrocarbons. Microb. Ecol. 2010, 60, 149-156. [CrossRef]

21. Isola, D.; Selbmann, L.; De Hoog, G.S.; Fenice, M.; Onofri, S.; Prenafeta-Boldú, F.X.; Zucconi, L. Isolation and Screening of Black Fungi as Degraders of Volatile Aromatic Hydrocarbons. Mycopathologia 2013, 175, 369-379. [CrossRef]

22. Gostinčar, C.; Muggia, L.; Grube, M. Polyextremotolerant black fungi: Oligotrophism, adaptive potential, and a link to lichen symbioses. Front. Microbiol. 2012, 3, 390. [CrossRef]

23. Cordero, R.J.B.; Vij, R.; Casadevall, A. Microbial melanins for radioprotection and bioremediation. Microb. Biotechnol. 2017, 10, 1186-1190. [CrossRef]

24. Gueidan, C.; Ruibal, C.; De Hoog, S.; Schneider, H. Rock-inhabiting fungi originated during periods of dry climate in the late Devonian and middle Triassic. Fungal Biol. 2011, 115, 987-996. [CrossRef]

25. Gostinčar, C.; Grube, M.; Gunde-Cimerman, N. Evolution of Fungal Pathogens in Domestic Environments? Fungal Biol. 2011, 115, 1008-1018. [CrossRef]

26. Gümral, R.; Tümgör, A.; Saraçlı, M.A.; Yıldıran, Ş.T.; Ilkit, M.; de Hoog, G.S. Black yeast diversity on creosoted railway sleepers changes with ambient climatic conditions. Microb. Ecol. 2014, 68, 699-707. [CrossRef]

27. Nascimento, M.M.; Vicente, V.A.; Bittencourt, J.V.; Gelinski, J.M.L.; Prenafeta-Boldú, F.X.; Romero-Güiza, M.; Fornari, G.; Gomes, R.R.; Santos, G.D.; Ende, A.G.V.D.; et al. Diversity of opportunistic black fungi on babassu coconut shells, a rich source of esters and hydrocarbons. Fungal Biol. 2017, 121, 488-500. [CrossRef]

28. Badali, H.; Prenafeta-Boldú, F.X.; Guarro, J.; Klaassen, C.H.; Meis, J.F.; De Hoog, G.S. Cladophialophora psammophila, a novel species of Chaetothyriales with a potential use in the bioremediation of volatile aromatic hydrocarbons. Fungal Biol. 2011, 115, 1019-1029. [CrossRef]

29. Prenafeta-Boldú, F.X.; Illa, J.; Van Groenestijn, J.W.; Flotats, X. Influence of synthetic packing materials on the gas dispersion and biodegradation kinetics in fungal air biofilters. Appl. Microbiol. Biotechnol. 2008, 79, 319-327. [CrossRef]

30. Teixeira, M.M.; Moreno, L.F.; Stielow, B.; Muszewska, A.; Hainaut, M.; Gonzaga, L.; Abouelleil, A.; Patané, J.S.L.; Priest, M.; Souza, R.; et al. Exploring the genomic diversity of black yeasts and relatives (Chaetothyriales, Ascomycota). Stud. Mycol. 2017, 86, 1-28. [CrossRef] [PubMed]

31. Blasi, B.; Tafer, H.; Kustor, C.; Poyntner, C.; Lopandic, K.; Sterflinger, K. Genomic and transcriptomic analysis of the toluene degrading black yeast Cladophialophora immunda. Sci. Rep. 2017, 7, 11436. [CrossRef] [PubMed]

32. Satow, M.M.; Attili-Angelis, D.; De Hoog, G.S.; Vicente, V.A. Selective factors involved in oil flotation isolation of black yeasts from the environment. Stud. Mycol. 2008, 61, 157-163. [CrossRef] [PubMed]

33. Standard Methods for the Examination of Water and Wastewater, 19th ed.; American Public Health Association: Washington, DC, USA, 1998.

34. Möller, E.M.; Bahnweg, G.; Sandermann, H.; Geiger, H.H. A simple and efficient protocol for isolation of high molecular weight DNA from filamentous fungi, fruit bodies, and infected plant tissues. Nucleic Acids Res. 1992, 20, 6115-6116. [CrossRef] 
35. Gerrits Van Den Ende, A.H.G.; De Hoog, G.S. Variability and molecular diagnostics of the neurotropic species Cladophialophora bantiana. Stud. Mycol. 1999, 43, 151-162.

36. White, T.J.; Bruns, T.D.; Lee, S.; Taylor, J. Analysis of phylogenetic relationships by amplification and direct sequencing of ribosomal RNA genes. In PCR Protocols: A Guide to Methods and Applications; Innis, M.A., Gelfand, D.H., Sninsky, J.J., White, T.J., Eds.; Academic Press: New York, NY, USA, 1990; pp. 315-322.

37. Hall, T.A. BioEdit: A User-Friendly Biological Sequence Alignment Editor and Analysis Program for Windows 95/98/NT; Nucleic Acids Symposium Series; Information Retrieval Ltd.: London, UK, 1999; Volume 41, pp. 95-98.

38. Altschul, S.F.; Gish, W.; Miller, W.; Myers, E.W.; Lipman, D.J. Basic local alignment search tool. J. Mol. Biol. 1990, 215 , 403-410. [CrossRef]

39. Larkin, M.A.; Blackshields, G.; Brown, N.P.; Chenna, R.; McGettigan, P.A.; McWilliam, H.; Valentin, F.; Wallace, I.M.; Lopez, R.; Thompson, J.D.; et al. ClustalW and ClustalX version 2. Bioinformatics 2007, 23, 2947-2948. [CrossRef]

40. Kumar, S.; Stecher, G.; Li, M.; Knyaz, C.; Tamura, K. MEGA X: Molecular evolutionary genetics analysis across computing platforms. Mol. Biol. Evol. 2018, 35, 1547-1549. [CrossRef]

41. Kimura, M. A simple method for estimating evolutionary rates of base substitutions through comparative studies of nucleotide sequences. J. Mol. Evol. 1980, 16, 111-120. [CrossRef]

42. Amoore, J.E.; Hautala, E. Odor as an aid to chemical safety: Odor thresholds compared with threshold limit values and volatilities for 214 industrial chemicals in air and water dilution. J. Appl. Toxicol. 1983, 3, 272-290. [CrossRef]

43. Huse, S.M.; Welch, D.B.M.; Voorhis, A.; Shipunova, A.; Morrison, H.G.; Eren, A.M.; Sogin, M.L. VAMPS: A website for visualization and analysis of microbial population structures. BMC Bioinform. 2014, 15, 41. [CrossRef]

44. De Hoog, G.S.; Queiroz-Telles, F.; Haase, G.; Fernandez-Zeppenfeldt, G.; Angelis, D.A.; Van Den Ende, A.; Matos, T.; PeltrocheLlacsahuanga, H.; Pizzirani-Kleiner, A.A.; Rainer, J.; et al. Black fungi: Clinical and pathogenic approaches. Med. Mycol. 2000, 38, 243-250. [CrossRef]

45. De Hoog, G.S.; Vicente, V.A.; Gorbushina, A.A. The bright future of darkness-The rising power of black fungi: Black yeasts, microcolonial fungi, and their relatives. Mycopathologia 2013, 175, 365-368. [CrossRef]

46. Moreno, L.F.; Ahmed, A.A.O.; Brankovics, B.; Cuomo, C.A.; Menken, S.B.J.; Taj-Aldeen, S.J.; Faidah, H.; Stielow, J.B.; Teixeira, M.D.M.; Prenafeta-Boldú, F.X.; et al. Genomic Understanding of an Infectious Brain Disease from the Desert. G3 Genes Genomes Genet. 2018, 8, 909-922. [CrossRef]

47. Moreno, L.F.; Mayer, V.; Voglmayr, H.; Blatrix, R.; Stielow, J.B.; Teixeira, M.M.; Vicente, V.A.; De Hoog, S. Genomic analysis of ant domatia-associated melanized fungi (Chaetothyriales, Ascomycota). Mycol. Prog. 2019, 18, 541-552. [CrossRef]

48. Badali, H.; Gueidan, C.; Najafzadeh, M.J.; Bonifaz, A.; Gerrits Van Den Ende, A.H.G.; De Hoog, G.S. Biodiversity of Cladophialophora. Stud. Mycol. 2008, 61, 175-191. [CrossRef]

49. De Hoog, G.S.; Nishikaku, G.; Fernandez-Zeppenfeldt, C.; Padín Gonzáles, E.; Badali, H.; Richar-Yegres, N.; Gerrits Van Den Ende, H.G. Molecular nalysis and pathogenicity of the Cladophialophora carrionii complex, with the description of a novel species. Stud. Mycol. 2007, 58, 219-234. [CrossRef]

50. Crous, P.W.; Braun, U.; Schubert, K.; Groenewald, J.Z. The genus Cladosporium and similar dematiaceous hypho-mycetes. Preface Stud. Mycol. 2007, 58, 253.

51. Madrid, H.; Hernandez-Restrepo, M.; Gené, J.; Cano, J.; Guarro, J.; Silva, V. New and interesting chaetothyrialean fungi from Spain. Mycol. Prog. 2016, 15, 1179-1201. [CrossRef]

52. Das, K.; Lee, S.-Y.; Jung, H.-Y. Cladophialophora lanosa sp. nov., a New Species Isolated from Soil. Mycobiology 2019, 47, 173-179. [CrossRef]

53. Nunes, T.; Pio, C. Emission of volatile organic compounds from Portuguese eucalyptus forests. Chemosphere Glob. Chang. Sci. 2001, 3, 239-248. [CrossRef]

54. Winters, A.J.; Adams, M.A.; Bleby, T.M.; Rennenberg, H.; Steigner, D.; Steinbrecher, R.; Kreuzwieser, J. Emissions of isoprene, monoterpene and short-chained carbonyl compounds from Eucalyptus spp. in southern Australia. Atmos. Environ. 2009, 43, 3035-3043. [CrossRef]

55. Napolitano, R.; Juaréz, N.P. Entomopathogenous fungi degrade epicuticular hydrocarbons of Triatoma infestans. Arch. Biochem. Biophys. 1997, 344, 208-214. [CrossRef]

56. Attili-Angelis, D.; Duarte AP, M.; Pagnocca, F.C.; Nagamoto, N.S.; De Vries, M.; Stielow, J.B.; de Hoog, G.S. Novel Phialophora species from leaf-cutting ants (tribe Attini). Fungal Divers. 2014, 65, 65-75. [CrossRef]

57. Sudhadham, M.; Prakitsin, S.; Sivichai, S.; Chaiyarat, R.; Dorrestein, G.; Menken, S.; de Hoog, G. The neurotropic black yeast Exophiala dermatitidis has a possible origin in the tropical rain forest. Stud. Mycol. 2008, 61, 145-155. [CrossRef]

58. Li, D.M.; Li, R.Y.; De Hoog, G.; Wang, Y.X.; Wang, D.L. Exophiala asiatica, a new species from a fatal case in China. Med. Mycol. 2009, 47, 101-109. [CrossRef]

59. Del Palacio-Hernanz, A.; Moore, M.K.; Campbell, C.K.; Del Palacio-Perez-Medel, A.; Del Castillo-Cantero, R. Infection of the central nervous system by Rhinocladiella atrovirens in a patient with acquired immunodeficiency syndrome. J. Med. Vet. Mycol. 1989, 27, 127-130. [CrossRef]

60. Fukasawa, Y. Fungal succession and decomposition of Pinus densiflora snags. Ecol. Res. 2018, 33, 435-444. [CrossRef]

61. Szewczyk, W.; Kwaśna, H.; Behnke-Borowczyk, J. Fungi inhabiting knotwood of Pinus sylvestris infected by Porodaedalea pini. J. Phytopathol. 2017, 165, 500-507. [CrossRef] 
62. Ruibal, C.; Gonzalo, P.; Bills, G.F. Isolation and characterization of melanized fungi from limestone formations in Mallorca. Mycol. Prog. 2005, 4, 23-38. [CrossRef]

63. Vicente, V.; Attili-Angelis, D.; Pie, M.; Queiroz-Telles, F.; Cruz, L.; Najafzadeh, M.; de Hoog, G.; Zhao, J.; Pizzirani-Kleiner, A. Environmental isolation of black yeast-like fungi involved in human infection. Stud. Mycol. 2008, 61, 137-144. [CrossRef] [PubMed]

64. Vicente, V.A.; Angelis, D.A.D.; Queiróz-Telles Filho, F.; Pizzirani-Kleiner, A.A. Isolamento de fungos herpotriquieláceos do ambiente. Braz. J. Microbiol. 2001, 32, 47-51.

65. Kirk, P.M.; Cannon, P.F.; Minter, D.W.; Staplers, J.A. Dictionary of the Fungi, 10th ed.; CABI Bioscience: Wallingford, UK, 2008.

66. Zhang, Y.; Crous, P.W.; Schoch, C.L.; Bahkali, A.H.; Guo, L.D.; Hyde, K.D. A molecular, morphological and ecological re-appraisal of Venturiales-A new order of Dothideomycetes. Fungal Divers. 2011, 51, 249-277. [CrossRef] [PubMed]

67. Boerema, H.G.; de Gruyter, J.; Noordeloos, E.M. Contributions towards a monograph of Phoma (Coelomycetes)—IV. Section Heterospora: Taxa with large sized conidial dimorphs, in vivo sometimes as Stagonosporopsis synanamorphs. Pers. Mol. Phylogeny Evol. Fungi 1997, 16, 335-371.

68. Boerema, G.H.; Gruyter, J.; Noordeloos, M.E.; Hamers, M.E.C. Phoma Identification Manual: Differentiation of Specific and InfraSpecific Taxa in C. Phoma Identification Manual: Differentiation of Specific and Infra-Specific Taxa in Culture; CABI: Wallingford, UK, 2004.

69. de Gruyter, J.; Woudenberg, J.; Aveskamp, M.; Verkley, G.; Groenewald, J.; Crous, P. Redisposition of phoma-like anamorphs in Pleosporales. Stud. Mycol. 2013, 75, 1-36. [CrossRef]

70. Ebead, G.A.; Overy, D.P.; Berrué, F.; Kerr, R.G. Westerdykella reniformis sp. nov., producing the antibiotic me-tabolites melinacidin IV and chetracin B. IMA Fungus 2012, 3, 189-201. [CrossRef]

71. Guedes, F.L.A.; Attili-Angelis, D.; Pagnocca, F.C. Selective isolation of dematiaceous fungi from the workers of Atta laevigata (Formicidae: Attini). Folia Microbiol. 2011, 57, 21-26. [CrossRef]

72. Dunn, M.; Domsch, K.H.; Gams, W.; Anderson, T.-H. Compendium of Soil Fungi. TAXON 1982, 31, 600. [CrossRef]

73. Alves, J.L.; Barreto, R.W.; Pereira, O.L.; Soares, D.J. Additions to the mycobiota of the invasive weed Miconia calvescens (Melastomataceae). Mycologia 2010, 102, 69-82. [CrossRef]

74. Costa, I.P.M.W.; Maia, L.C.; Cavalcanti, M.A. Diversity of leaf endophytic fungi in mangrove plants of Northeast Brazil. Braz. J. Microbiol. 2012, 43, 1165-1173. [CrossRef]

75. Luo, J.; Liu, X.; Li, E.; Guo, L.; Che, Y. Arundinols A-C and Arundinones A and B from the Plant Endophytic FungusMicrosphaeropsis arundinis. J. Nat. Prod. 2012, 76, 107-112. [CrossRef] [PubMed]

76. Luedemann, G.M. The Dictyochlamydospore of Peyronellaea glomerata (Corda) Goidanich ex Togliani Contrasted with the Dictyoporospore of Alternaria Tenuis Auct. Mycologia 1959, 51, 772-780. [CrossRef]

77. Deng, J.X.; Paul, N.C.; Li, M.J.; Seo, E.Y.; Sung, G.H.; Yu, S.H. Molecular Characterization and Morphology of Two Endophytic Peyronellaea Species from Pinus koraiensis in Korea. Mycobiology 2011, 39, 266-271. [CrossRef] [PubMed]

78. Abdollahzadeh, J.; Groenewald, J.Z.; Coetzee MP, A.; Wingfield, M.J.; Crous, P.W. Evolution of lifestyles in Capnodiales. Stud. Mycol. 2020, 95, 381-414. [CrossRef]

79. Crous, P.; Summerell, B.; Carnegie, A.; Wingfield, M.; Groenewald, J. Novel species of Mycosphaerellaceae and Teratosphaeriaceae. Persoonia Mol. Phylogeny Evol. Fungi 2009, 23, 119-146. [CrossRef]

80. Bensch, K.; Groenewald, J.; Dijksterhuis, J.; Starink-Willemse, M.; Andersen, B.; Summerell, B.; Shin, H.-D.; Dugan, F.; Schroers, H.-J.; Braun, U.; et al. Species and ecological diversity within the Cladosporium cladosporioides complex (Davidiellaceae, Capnodiales). Stud. Mycol. 2010, 67, 1-94. [CrossRef]

81. Rodrigues, A.; Cable, R.N.; Mueller, U.G.; Bacci, M., Jr.; Pagnocca, F.C. Antagonistic interactions between garden yeasts and microfungal garden pathogens of leafcutting ants. Antonie Leeuwenhoek 2009, 96, 331-342. [CrossRef]

82. Rodrigues, A.; Mueller, U.G.; Ishak, H.D.; Bacci, M., Jr.; Pagnocca, F.C.; Bacci, M. Ecology of microfungal communities in gardens of fungus-growing ants (Hymenoptera: Formicidae): A year-long survey of three species of attine ants in Central Texas. FEMS Microbiol. Ecol. 2011, 78, 244-255. [CrossRef]

83. Pagnocca, F.C.; Rodrigues, A.; Nagamoto, N.S.; Bacci, M. Yeasts and filamentous fungi carried by the gynes of leaf-cutting ants. Antonie Leeuwenhoek 2008, 94, 517-526. [CrossRef]

84. Mullins, J. Microorganisms in outdoor air. In Microorganisms in Home and Indoor Work Environments: Diversity, Health Impacts, Investigation and Control, 1st ed.; Flannigan, B., Samson, R.A., Miller, J.D., Eds.; Taylor \& Francis: London, UK, 2001; pp. 3-16.

85. Bensch, K.; Braun, U.; Groenewald, J.; Crous, P. The genus Cladosporium. Stud. Mycol. 2012, 72, 1-401. [CrossRef]

86. Bensch, K.; Groenewald, J.Z.; Braun, U.; Dijksterhuis, J.; de Jesús Yáñez-Morales, M.; Crous, P.W. Common but dif-ferent: The expanding realm of Cladosporium. Stud. Mycol. 2015, 82, 23-74. [CrossRef]

87. Sandoval-Denis, M.; Gené, J.; Sutton, D.; Wiederhold, N.; Cano-Lira, J.; Guarro, J. New species of Cladosporium associated with human and animal infections. Persoonia Mol. Phylogeny Evol. Fungi 2016, 36, 281-298. [CrossRef]

88. Bensch, K.; Groenewald, J.Z.; Meijer, M.; Dijksterhuis, J.; Jurjević, Ž.; Andersen, B.; Samson, R.A. Cladosporium species in indoor environments. Stud. Mycol. 2018, 89, 177-301. [CrossRef]

89. Quaedvlieg, W.; Binder, M.; Groenewald, J.Z.; Summerell, B.A.; Carnegie, A.J.; Burgess, T.I.; Crous, P.W. Intro-ducing the Consolidated Species Concept to resolve species in the Teratosphaeriaceae. Persoonia Mol. Phylogeny Evol. Fungi $2014,33,1$. [CrossRef] 
90. Duarte, A.; Attili-Angelis, D.; Baron, N.; Groenewald, J.; Crous, P.; Pagnocca, F. Riding with the ants. Persoonia Mol. Phylogeny Evol. Fungi 2017, 38, 81-99. [CrossRef]

91. Benny, G.L.; Kimbrough, J.W. A synopsis of the orders and families of Plectomycetes with keys to genera. Mycotaxon 1980, 12, $1-91$.

92. Bibashi, E.; De Hoog, G.S.; Kostopoulou, E.; Tsivitanidou, M.; Sevastidou, J.; Geleris, P. Invasive infection caused by Pseudallescheria boydii in an immunocompetent patient. Hippokratia 2009, 13, 184-186.

93. Martin-Sanchez, P.M.; Gorbushina, A.A.; Toepel, J. Quantification of microbial load in diesel storage tanks using culture- and qPCR-based approaches. Int. Biodet. Biodegr. 2016, 126, 216-223. [CrossRef]

94. Cazarolli, J.C.; Guzatto, R.; Samios, D.; Peralba, M.D.C.R.; Cavalcanti, E.H.D.S.; Bento, F.M. Susceptibility of linseed, soybean, and olive biodiesel to growth of the deteriogenic fungus Pseudallescheria boydii. Int. Biodeterior. Biodegrad. 2014, 95, 364-372. [CrossRef]

95. Janda-Ulfig, K.; Ulfig, K.; Cano, J.; Guarro, J. A study of the growth of Pseudallescheria boydii isolates from sewage sludge and clinical sources on tributyrin, rapeseed oil, biodiesel oil and diesel oil. Ann. Agric. Environ. Med. 2008, 15, 45-49.

96. April, T.M.; Abbott, S.P.; Foght, J.M.; Currah, R.S. Degradation of hydrocarbons in crude oil by the ascomycete Pseudal-lescheria boydii (Microascaceae). Can. J. Microbiol. 1998, 44, 270-278. [CrossRef] [PubMed]

97. Smith, G.J.; Liew, E.C.; Hyde, K.D. The Xylariales: A Monophyletic Order Containing 7 Families. Fungal Divers. 2003. Available online: http:/ / citeseerx.ist.psu.edu/viewdoc/summary?doi=10.1.1.515.7160 (accessed on 5 May 2021).

98. Maharachchikumbura, S.S.N.; Guo, L.-D.; Cai, L.; Chukeatirote, E.; Wu, W.P.; Sun, X.; Crous, P.W.; Bhat, D.J.; McKenzie, E.H.C.; Bahkali, A.H.; et al. A multi-locus backbone tree for Pestalotiopsis, with a polyphasic characterization of 14 new species. Fungal Divers. 2012, 56, 95-129. [CrossRef]

99. Maharachchikumbura, S.; Hyde, K.; Groenewald, J.; Xu, J.; Crous, P. Pestalotiopsis revisited. Stud. Mycol. 2014, 79, 121-186. [CrossRef] [PubMed]

100. Samerpitak, K.; Van der Linde, E.; Choi, H.-J.; Ende, A.H.G.G.V.D.; Machouart, M.; Gueidan, C.; de Hoog, G.S. Taxonomy of Ochroconis, genus including opportunistic pathogens on humans and animals. Fungal Divers. 2014, 65, 89-126. [CrossRef]

101. Viana-Bailez, A.M.; Bailez, O.; Malaquias, K.S. Comunicação Química em Formigas-Cortadeiras. In Formigas-Cortadeiras: Da Bioecologia ao Manejo, 1st ed.; Della-Luccia, T.M.C., Ed.; UFV: Abbotsford, BC, Canada, 2011.

102. Randall, J.D.; Hemmingsen, B.B. A critical evaluation of the fume plate method for the enumeration of bacteria capable of growth on volatile hydrocarbons. In Applied Biotechnology for Site Bioremediation; Hinchee, R.E., Anderson, D.B., Sayles, G.D., Eds.; Lewis Publishers: Boca Raton, FL, USA, 1994; pp. 400-404.

103. Blasi, B.; Poyntner, C.; Rudavsky, T.; Prenafeta-Boldú, F.X.; De Hoog, S.; Tafer, H.; Sterflinger, K. Pathogenic yet environmentally friendly? Black fungal candidates for bioremediation of pollutants. Geomicrobiol. J. 2016, 33, 308-317. [CrossRef] [PubMed]

104. Dolatabadi, S.; Rezaei-Matehkolaei, A.; Pawlowska, J.; Hosseini, S.A.; Najafzadeh, M.J.; Madrid, H. Chaetothy-rialean fungi from aromatic hydrocarbon-polluted environments of Iran. Nova Hedwig. 2016, 405-426.

105. Wainwright, M.; Ali, T.A.; Barakah, F. A review of the role of oligotrophic micro-organisms in biodeterioration. Int. Biodeterior. Biodegrad. 1993, 31, 1-13. [CrossRef]

106. Parkinson, S.M.; Wainwright, M.; Killham, K. Observations on oligotrophic growth of fungi on silica gel. Mycol. Res. 1989, 93, 529-534. [CrossRef]

107. Zhdanova, N.N.; Zakharchenko, V.A.; Vember, V.V.; Nakonechnaya, L.T. Fungi from Chernobyl: Mycobiota of the inner regions of the containment structures of the damaged nuclear reactor. Mycol. Res. 2000, 104, 1421-1426. [CrossRef]

108. Dadachova, E.; Bryan, R.A.; Huang, X.; Moadel, T.; Schweitzer, A.D.; Aisen, P.; Nosanchuk, J.D.; Casadevall, A. Ionizing Radiation Changes the Electronic Properties of Melanin and Enhances the Growth of Melanized Fungi. PLoS ONE 2007, 2, e457. [CrossRef]

109. Onofri, S.; Selbmann, L.; Zucconi, L.; Pagano, S. Antarctic microfungi as models for exobiology. Planet. Space Sci. 2004, 52, $229-237$. [CrossRef] 